\title{
Solar Photovoltaic Systems on Public Schools Buildings: A Case Study in Palestine
}

\author{
Husain Alsamamra ${ }^{1, *}$, Jawad Shoqeir ${ }^{2, ~ * ~}$ \\ ${ }^{1}$ Department of Physics, Al-Quds University, Jerusalem, Abu-Dies, Palestine \\ ${ }^{2}$ Department of Earth and Environmental sciences, Al-Quds University, Jerusalem, Abu-Dies, Palestine
}

Email address:

hsamamra@staff.alquds.edu (H. Alsamamra), jhassan@staff.alquds.edu (J. Shoqeir)

${ }^{*}$ Corresponding author

\section{To cite this article:}

Husain Alsamamra, Jawad Shoqeir. Solar Photovoltaic Systems on Public Schools Buildings: A Case Study in Palestine. American Journal of Electrical Power and Energy Systems. Vol. 10, No. 1, 2021, pp. 1-5. doi: 10.11648/j.epes.20211001.11

Received: January 22, 2021; Accepted: January 30, 2021; Published: February 9, 2021

\begin{abstract}
Renewable energy exploitation has proved its promising characteristics in sustainably securing energy needs. This work is a comprehensive assessment of the potential of renewable penetration in securing electricity needs in Palestine. Methods of assessment have been determined based on solar potential. Al-Dahriya secondary school in the south Hebron directorate of education was used as a case study, where these building have low working hours all over the year, which will increase the total income of the annual solar energy. AutoCad software simulation program was used to draw the rooftop of the school. The powerful HOMER Pro ${ }^{\mathrm{R}}$ software was used for the simulation processes of the PV system and its requirements. Results showed that, the rooftop could accommodate 144 panels, with $57.16 \mathrm{KW}$. This system will produce $92,866 \mathrm{KWh}$ every year, which could be an input of $5.12 \%$ of the total annual power consumption in Palestine if this system installed on every school in Palestine, which are in total 3074 schools. Due to the number of working hours and low energy consumption in schools, the payback period of the project will be 4.38 years. The income of the surplus when installing such project on all schools in Palestine will be around 43 million USD to the Palestinian Treasury every year after the payback period.
\end{abstract}

Keywords: Solar Energy, PV Panels, Power Consumption, Energy Security, Palestine

\section{Introduction}

The world is moving in fast steps toward more exploitation for renewable resources in all aspects of life [1, 2]. Fossil fuels are becoming scarcer and the emissions of burning fossil fuels have been proved to be harmful to human health and the stability of the environment $[3,4]$. Also, fossil fuel supplies to the energy market became intermittent due to political confrontations and considerations [5]. As a result, the employment of authentic resources of energy from nature to secure energy demand became a strong trend in the energy sector $[6,7]$. Today the world tends to use renewable and green energy sources in order to generate energy to preserve the environment.

Palestine is a developing occupied country which has a complicated energy sector, different from other countries in the Middle East. The energy sector is Palestine suffers from the implications of the Israeli occupation [8]. Gaza Strip and the West Bank are separated from each other. Gaza Strip is under siege since 2007, Israel applies strict bars on energy supplies to Gaza Strip. West Bank is divided into three administrative regions A, B \& C. However, Palestine is distinguished by promising capabilities of solar, wind and biomass resources, most of Palestine receives solar radiation about 3000 hours annually, and the average solar radiation values range from $5.4 \mathrm{kWh} / \mathrm{m}^{2}$.day to $6.0 \mathrm{kWh} / \mathrm{m}^{2}$.day [9]. These values show a reasonable potential for exploitation feasibility compared to other places worldwide such as Madrid-Spain $4.88 \mathrm{kWh} / \mathrm{m}^{2}$.day, Sydney-Australia 4.64 $\mathrm{kWh} / \mathrm{m}^{2}$.day [10].

In Palestine, energy prices are considered the highest in the region [11]. Since the industry relies on electricity for running different production lines, the volatility of energy prices is a major factor affecting this sector. Since Palestine is an occupied country, there is no possible free electricity trading with neighboring countries [12]. Thus, dealing with the unfair opposed prices of electricity is a daily fact that 
hinders the prosperity and growth of this sector, and many other sectors [13].

Hence, renewable energy sources such as solar energy, wind energy and others need large areas to become effective, hence the idea of this work by exploiting unused and wasted spaces to become a place for energy generation. Here in Palestine, the trend to renewable energy sources started about 15 years ago [14], but they are still weak due to the occupation policies that prevent the residents of Palestine from exploiting the resources as required [15]. According to the Palestinian Central Bureau of Statistics in 2018, Palestine consumed about 5,576 Giga watt hour of electricity, and about 931 tons of oil equivalent of Oil derivatives and 169 tons of oil equivalent of energy from renewable energy [16].

According to the Palestinian Central Bureau of Statistics (PCBS) in 2020, there are 3,074 schools in the West-bank and Gaza strip [17], these schools are closed more than 180 days in summer vacation, moreover, the schools work 7 hours maximum every day. The roof top of the schools are almost empty, so it is important to use that space over the roof to generate electricity, were the energy produced by the solar panels could be more than the energy consumed by the school all over the year.

The rooftop solar PV systems for schools will provide several benefits for Palestinian economy, contribute to and enhance the authority's plans and strategies to reduce dependence on other countries. Such projects will create significant savings in the cost of electricity bills for schools, it will cover part of the schools' expenses, also will creating awareness of green power in public schools and weaving sustainable energy practices into Palestine's teaching environment, also such projects will generate benefits for Palestinian electricity distribution companies and municipalities by making electricity available at lower costs than what is currently available from occupation authorities, in addition to reducing technical losses and at the national level, such systems will brings Palestine closer to energy independence and strengthens the country's commitment to renewable energy.

The Palestinian Ministry of Education developed a national program to deploy solar PV systems on the rooftops of public schools in Palestine. Directorate of education of south Hebron schools were divided into three classes according to the size of the school depending on the number of students and the size of the building, small, medium and large schools. Were the small schools have a roof space of 400 square meters, medium of 600 square meters and large schools have a roof space of 750 square meters. These schools consume electricity in summer months greater than in the winter period, as the average monthly consumption in summer for small schools is $300 \mathrm{KWh}, 400 \mathrm{KWh}$ for medium and $500 \mathrm{KWh}$ for large schools. As for the winter consumption rate, it is $350 \mathrm{KWh}$ for small schools, $450 \mathrm{KWh}$ for medium and $550 \mathrm{KWh}$ for large schools [18]. The annual school consumption in Palestine around 16.6 GWh, which is $0.3 \%$ of the total annul electricity consumption in Palestine.

This work aims to enhance the use of solar energy due to its high potential in Palestine, in order to help reducing the burden of school electricity bills. In this paper, Al-Dahriya secondary school from south Hebron directorate of education was considered as a case study. To assess the potential penetration of solar energy in securing the electricity needs based on the school criteria such as the site, available spaces, energy consumption profile and its surplus to the grid. Assess the techno-economic performance for proposed solar systems. The simulation software that is used to run the realtime simulation is HOMER Pro $^{\mathrm{R}}$ (Hybrid Optimization Model for Multiple Energy Resources), this software will be used for different types of analysis in this work. It's worthy to mention, that the feasible forms of electricity producing renewable energy systems, in this case, are only solar energy, other sources will not be considered in this study due to infeasibility.

The following sections of this paper are structured as follows: Methodology, results and discussion, and conclusion.

\section{Methodology}

To conduct the study, the work were divided into 3 phases. First, gathering the site information, history of electricity consumption and solar data. Second, the AutoCad was used to draw the Pv panels on the rooftop of the school, and then applying the data of the school to HOMER Pro ${ }^{\mathrm{R}}$ software [19] to calculate the amount of the PV system needed and then calculate the power output, this software is generally considered to be a powerful and comprehensive program and commonly used for design and simulation of solar power plants, including grid-connected systems. In addition, this simulation tool can prove useful to calculate economic and environmental indicators. Finally, the total cost of implementing the project on the study site will be calculated, the surplus, the expected period to recover the cost of the project from surplus investment with the national electricity distribution company in Palestine.

The available solar modules in the market today is Canadian Solar and was classified as one of the top preferred module brands as of 2019 as mentioned in OhmHome summary recommendation of solar modules[20]. The CS1U$415 \mathrm{Wp}$ solar module was distinguished to have a substantial efficiency in CS1U Series with $20.13 \%$ efficiency per cell area. The modules have to be oriented in landscape configuration to avoid the effect of parallel shading on the module cells. This system will produce $57.16 \mathrm{KW}$. The solar panels were installed with column space of $5 \mathrm{~cm}$ and row space of 1.16 meters to reduce the shadows, on tilt angle of 23 degree to the south which is the best in Palestine [21].

Al-Dahriya town located in the southern part of the West Bank $31^{\circ} 24^{\prime} 35^{\prime \prime} \mathrm{N}$ : $34^{\circ} 58^{\prime} 24^{\prime \prime} \mathrm{E}$, as shown in figure 1, with the semi-desert climate make it one of the most suitable locations for applying solar power systems as a part of successful solar energy resources. Al-Dahriya secondary school located in Al-Dahriya town, and administratively follow to south Hebron directorate of education were chosen 
to be a case study because it has a medium roof space so it will give a good indication to the other school sizes. It has a rooftop space of 670 square meters and the available area for the installation of solar panels is 490 square meters due to shadows and because of the space left for future movement for maintenance.

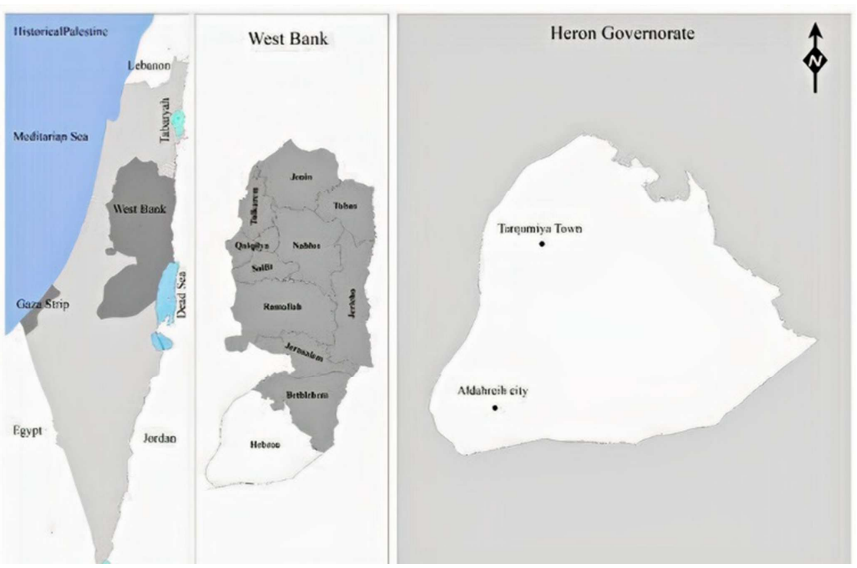

Figure 1. Location of Al-Dahriya Town.

\section{Results and discussion}

The monthly average of solar radiation at the study site presented in figure 2, it is follow the normal distribution and the maximum values of the received solar radiation are in summer months (June to August) with a maximum value of $7.74 \mathrm{KWh} / \mathrm{m}^{2} /$ day in July, while the minimum values are in winter months (November to January) with a minimum value of $3.07 \mathrm{KWh} / \mathrm{m}^{2} /$ day in December.

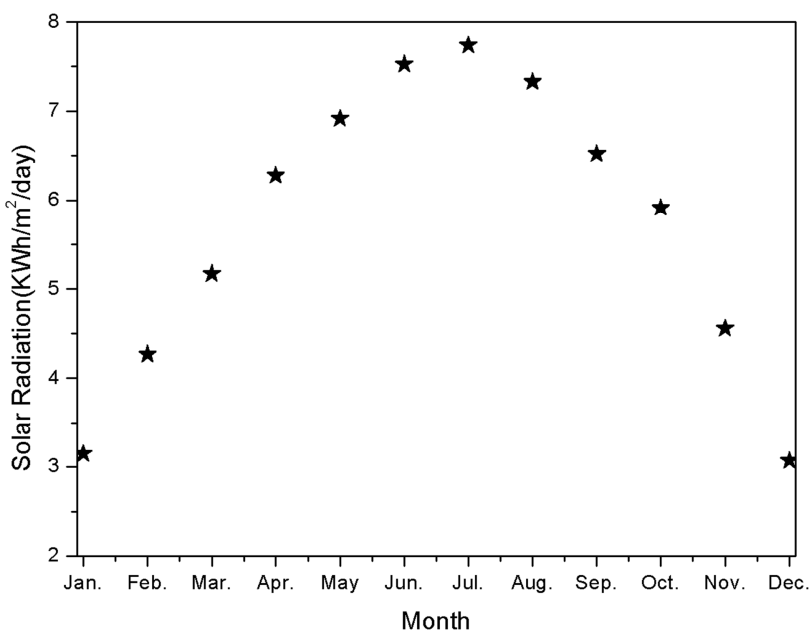

Figure 2. Monthly average solar radiation at the study site.

The rooftop school presents no shading and panels can be installed without any limitations. After applying the data on the AutoCad and HOMER Pro ${ }^{\mathrm{R}}$ software, 144 PV panel could be installed in the available area, and costs approximately 65,000 USD, and produce 92,866 KWh yearly. However, the school energy consumed $4,237 \mathrm{KWh}$ in the year 2019, and the consumption usually decreased in June, July and August because it is the summer vacation, but the production increasing in these months because they have the longest sunshine duration all over the year as shown in figure 3 .

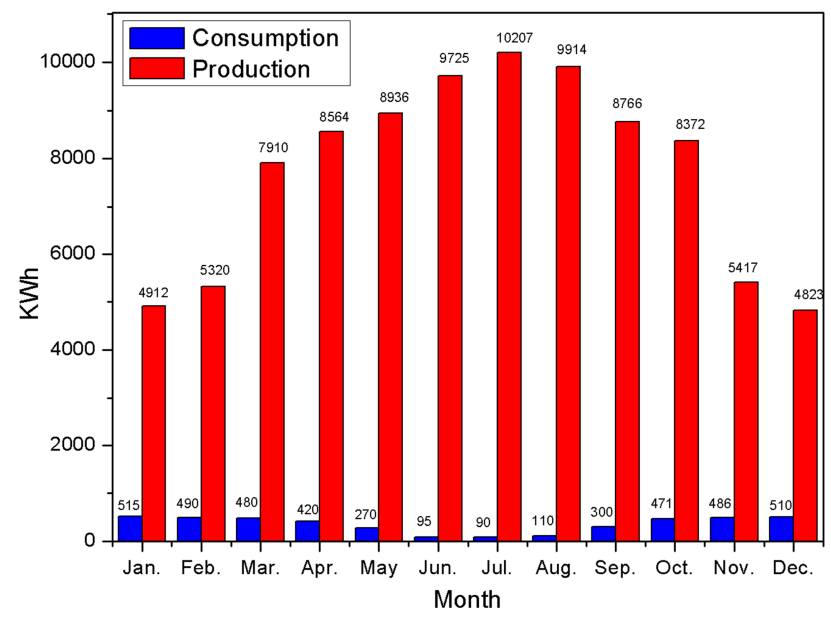

Figure 3. Monthly Ac consumption and production (KWh).

From the results shown in figure 3 , it was found that the difference between consumption and production is large and this is due to the absence of energy-consuming electrical systems in Palestinian schools, such as heating and cooling systems, since the weather in Palestine in spring, summer and autumn seasons does not need cooling systems in schools as the weather is moderate, except for Jericho city, which is located In the Jordan Valley, they need cooling systems. In winter season schools need heating systems, but the economic situation in Palestine does not allow the installation of such systems in schools.

Moreover, the HOMER Pro ${ }^{\mathrm{R}}$ software calculated the solar radiation, the plane of array irradiance and the DC array output for the system as shown in table 1.

Table 1. Specifications of the PV system.

\begin{tabular}{lllll}
\hline Month & $\begin{array}{l}\text { Ac output } \\
\text { (KWh) }\end{array}$ & $\begin{array}{l}\text { Solar } \\
\text { Radiation } \\
\left(\mathbf{K W h} / \mathbf{m}^{2} / \mathbf{d a y}\right)\end{array}$ & $\begin{array}{l}\text { Plane of array } \\
\text { irradiance } \\
\left(\mathbf{w} / \mathbf{m}^{\mathbf{2}}\right)\end{array}$ & $\begin{array}{l}\text { Dc output } \\
(\mathbf{K W h})\end{array}$ \\
\hline January & 4911.87 & 3.15 & 112.33 & 5334.12 \\
February & 5320.11 & 4.27 & 127.16 & 5742.92 \\
March & 7909.92 & 5.17 & 173.13 & 8521.65 \\
April & 8564.13 & 6.28 & 197.02 & 8940.42 \\
May & 8936.02 & 6.92 & 222.3 & 9320.23 \\
June & 9724.89 & 7.53 & 236.14 & 10.255 .14 \\
July & 10207.1 & 7.74 & 241.77 & 10670.15 \\
August & 9913.95 & 7.33 & 235.63 & 10436.78 \\
September & 8766.14 & 6.52 & 220.45 & 9633.46 \\
October & 8371.77 & 5.91 & 204.17 & 8877.81 \\
November & 5417.12 & 4.56 & 191.34 & 5917.28 \\
December & 4823.04 & 3.07 & 109.72 & 5240.73 \\
\hline
\end{tabular}

The calculations of the surplus by drop the consumed value from the produced value provide 88,629 KWh Ac surplus value for 12 months, as shown in figure 4 . The annual surplus electricity is equivalent to $14181 \mathrm{USD}$, which is a good amount that can be obtained from only one school out of 3074 schools in Palestine. 


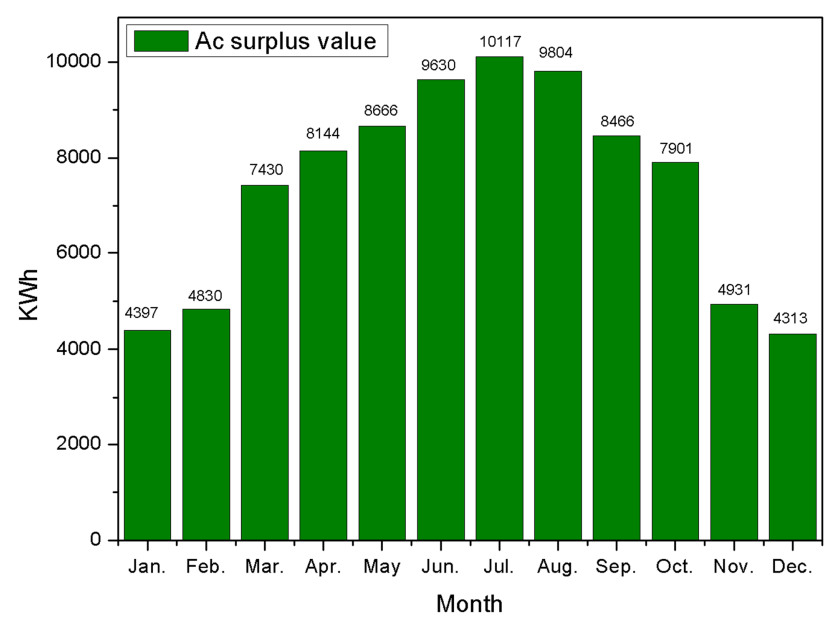

Figure 4. Monthly Ac surplus (KWh).

The payback period was calculated upon the production of the system and found to be 4.38 years, were the school will have a total income about 14181 USD every year after the power consumed, however the tariff of each $1 \mathrm{KWh}$ is 0.16 USD [22], which means that the school will win a total income about 283620 USD after 20 years which is the life span of the system as presented in figure 5 .

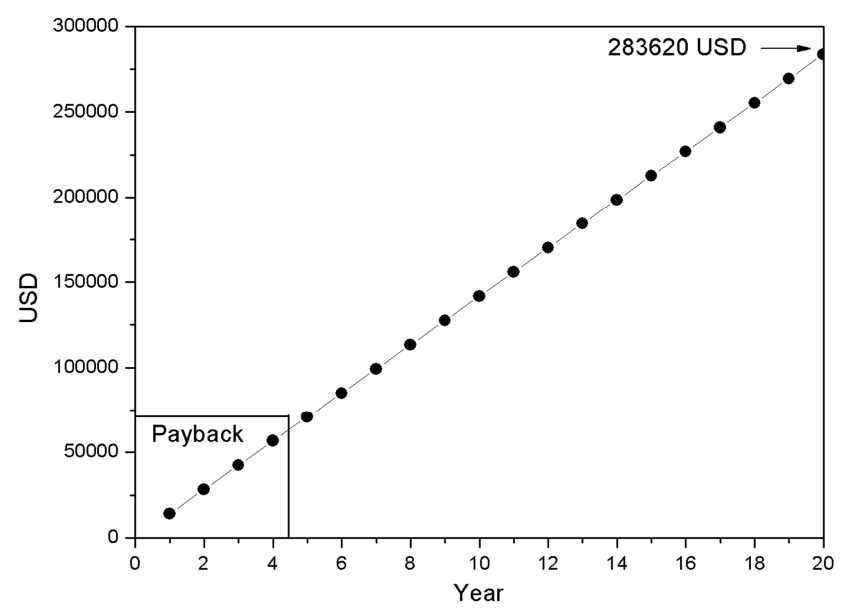

Figure 5. Total income over 20 years.

Roof top solar PV system on schools is feasible and can generate the consumption of schools by installing PV panels on the rooftop, usually these installations at the tail-end of the grid therefore they can enhance grid-stability and reduce power losses in grid savings in land requirement for solar installations, and savings in development of new distribution infrastructure because it will reduce the current flow in distribution network, its considered as a good example for distributed power generation sources.

\section{Conclusion}

Installing PV systems on the rooftop of the Palestinian public schools will help Palestinians to be closer to energy independence and encourages its commitment to renewable energy as well as creating environmental education of green energy in schools, in addition to the sustainable energy practices to Palestine's teaching environment.

Al-Dahriya secondary has an available area of 490 square meters for PV panel's installation of its total area 670 square meters. The calculation shows that its rooftop could handle a PV system of $57.16 \mathrm{KW}$, with $144 \mathrm{PV}$ panels. This system will produce annually $92,866 \mathrm{KWh}$ of solar electricity, were the total annual consumption of the school is $4,237 \mathrm{KWh}$. The annual surplus electricity was found to be $88629 \mathrm{KW}$, which means an annual income of 14,181 USD, were the total cost of the system about 65,000 USD. The calculations found the payback period to be 4.38 years, the total income after 20 years which is the life span of the system about 283,620 USD. Moreover, when applying this system on the 3,074 schools in Palestine, the system will produce $5.12 \%$ of the Palestinian annual consumption in addition to the $0.3 \%$ consumption of schools. Installing such a project on all schools means that the Palestinian Treasury will have an annual significant save around 43 million USD after around 5 years payback period. Future studies can be done on the feasibility of using small scale wind turbines.

\section{Conflicts of Interest}

The authors declare no conflicts of interest regarding the publication of this paper.

\section{Acknowledgements}

The authors would like to thank south Hebron directorate of education for their help.

\section{References}

[1] Alsamamra, H. and Shoqeir J. (2020) Assessment of Wind Power Potential at Eastern-Jerusalem, Palestine. Open Journal of Energy Efficiency, 9, 131-149.

[2] Barbir, F. Veziroğlu, T. and Plass, H. (1990) Environmental damage due to fossil fuels use. International Journal of Hydrogen Energy, 15, 739-749.

[3] Kishore, P. and Kisiel, J. (2013) Exploring High School Students' Perceptions of Solar Energy and Solar Cells. International Journal of Environmental and Science Education, 8, 521-534.

[4] Jamil, M. Kirmani, S. and Rizwan, M. (2012) Techno-economic feasibility analysis of solar photovoltaic power generation: A review. Smart Grid Renewable Energy, 3, 266-275.

[5] Taibi, E. Gielen, D. and Bazilian, M. (2012) The potential for renewable energy in industrial applications. Journal of Renewable and Sustainable Energy Reviews, 16, 735-744.

[6] Hernandez-Escobedo, Q. and Ramirez-Jimenez, A. (2020) Sustainable Solar Energy in Mexican Universities. Case Study: The National School of Higher Studies Juriquilla (UNAM), Sustainability, 12, 3123-3131.

[7] Masters, G. Renewable and efficient electric power systems. 2013: John Wiley \& Sons. 
[8] Ibrik, I. and Mahmoud, M. (2005) Energy efficiency improvement procedures and audit results of electrical, thermal and solar applications in Palestine, Energy Policy, 33, 651-658.

[9] Juaidi, A. and Montoya, F. (2016) An overview of renewable energy potential in Palestine, Renewable and Sustainable Energy Reviews, 65, 943-960.

[10] Ouda, M. Prospects of Renewable Energy in Gaza Strip. Energy Research Development Center, Islamic University of Gaza, Palestine, 2003.

[11] Abu-Hafeetha, M. F. F. Planning for Solar Energy as an Energy Option in Palestine. 2009.

[12] Ismail, M. Moghannemi, M. and Mahila, T. (2013) Analysis and evaluation of various aspects of solar radiation in the Palestinian territories, Energy Conversion and Management, 73, 57-68.

[13] Omar, M. and Mahmoud, M. (2018) Economic evaluation of residential grid connected PV Systems based on NetMetering and Feed-in- Tariff schemes in Palestine. International Journal of Renewable Energy Research, 8 (4), 16-27.

[14] Alsamamra, H. (2019) Estimation of Global Solar Radiation from Temperature Extremes: A Case Study of Hebron City, Palestine, Journal of energy and natural resources, 8, 1-5.

[15] PCBS, Energy consumptionby sector, energy form abd year between 2014 and 2018, Palestinian Central Bureau of
Statistics, 2020. [Online]. Available: http://www.pcbs.gov.ps/Portals/_Rainbow/Documents/Schools _ar.html.

[16] Ibrik, I. and Hashaika, F. (2019) Techno-Economic Impact of Grid-Connected Rooftop Solar Photovoltaic System for Schools in Palestine: A Case Study of Three Schools, International Journal of Energy Economics and Policy, 3, 291-300.

[17] M. O. E. Facts and Numbers," Palestinian Ministry of Education, 2019. [Online]. Available: http://www.moehe.gov.ps/moehe/factsandfigures.

[18] Alabadla, Z. and Schlin, U. (2020) Global Solar Radiation Analysis and Possible Linked to Sunspots Number over Gaza, Palestine, Materials and Environmental Science, 10, 15031511.

[19] HOMER-Energy. HOMER Pro Microgrid. 2020; Available from: www.homerenergy.com

[20] "Best Solar Panel Brands - Ranking and Trends", Ohm Home, 2019, Available: https://www.ohmhomenow.com/best-solarpanel-brands/.

[21] Ajlouni, E. and Alsamamra, H. (2019) A Review of Solar Energy Prospects in Palestine, American Journal of Modern Energy, 5, 49-62.

[22] P. E. R. C. Renewable energy laws and legislation," Palestinian Electricity Sector Regulatory Council, 2015. [Online]. Available: https://perc.ps/perc/?page_id=85. 